\title{
Towards optimal education including self-regulated learning in technology-enhanced preschools and primary schools
}

Citation for published version (APA):

Mooij, T., Dijkstra, E., Walraven, A., \& Kirschner, P. A. (2014). Towards optimal education including selfregulated learning in technology-enhanced preschools and primary schools. European Educational Research Journal, 13(5), 529-552. https://doi.org/10.2304/eerj.2014.13.5.529

DOI:

10.2304/eerj.2014.13.5.529

Document status and date:

Published: 01/10/2014

Document Version:

Peer reviewed version

\section{Document license:}

CC BY-SA

Please check the document version of this publication:

- A submitted manuscript is the version of the article upon submission and before peer-review. There can be important differences between the submitted version and the official published version of record. People interested in the research are advised to contact the author for the final version of the publication, or visit the DOI to the publisher's website.

- The final author version and the galley proof are versions of the publication after peer review.

- The final published version features the final layout of the paper including the volume, issue and page numbers.

Link to publication

\section{General rights}

Copyright and moral rights for the publications made accessible in the public portal are retained by the authors and/or other copyright owners and it is a condition of accessing publications that users recognise and abide by the legal requirements associated with these rights.

- Users may download and print one copy of any publication from the public portal for the purpose of private study or research.

- You may not further distribute the material or use it for any profit-making activity or commercial gain

- You may freely distribute the URL identifying the publication in the public portal.

If the publication is distributed under the terms of Article 25fa of the Dutch Copyright Act, indicated by the "Taverne" license above, please follow below link for the End User Agreement:

https://www.ou.nl/taverne-agreement

Take down policy

If you believe that this document breaches copyright please contact us at:

pure-support@ou.nl

providing details and we will investigate your claim.

Downloaded from https://research.ou.nl/ on date: 26 Apr. 2023 


\title{
Mooij, T., Dijkstra, E.M., Walraven, A., \& Kirschner, P.A. (in press). Towards optimal education including self-regulated learning in technology-enhanced preschools and primary schools. European Educational Research Journal.
}

\begin{abstract}
At the start of preschool, four-year-old pupils differ in their development, including in their capacity to self-regulate their playing and learning. In preschool and primary school, educational processes are generally adapted to the mean age of the pupils in class. The same may apply to ICT-based pupil-monitoring systems. This norm-based factor undermines the potential of ICT to support the educational differentiation needed for pupils and increases the amount of daily work for teachers. A theoretical framework is sketched in which pedagogical-didactical, organisational, and ICT guidelines enhance differentiated, self-regulated playing and learning for each pupil within preschool and primary school. To develop and check such optimal education and ICT conditions in practice, a pilot and a randomised intervention study are carried out in integrated Dutch preschools/primary schools for pupils aged $4-12$. Pilot results support the use of a procedure to screen each child's characteristics at the start of preschool by parents and preschool teachers, and also the immediate relevance of criterion-based and norm-based ordering ('double diagnostics') of playing and learning materials. Final attention is given to the intervention study and further development of optimal education in a European research context.
\end{abstract}

\section{Introduction}

Human learning is characterised by continuous interactions between innate potential and abilities on the one hand and different types of environments on the other; each side may contribute to the learner's growth (Magnusson \& Allen, 1983). The learning of a young child is influenced, then, by the home situation, which also reflects the level of educational attainment of the parents, in particular the mother (Moss \& Strayer, 1990; Robinson, Burns, \& Winder Davis, 2009; Pino-Pasternak \& Whitebread, 2010). Opportunities for relative autonomy or self-regulation in playing, and parental support for educational achievement are generally more evident in homes characterised by relatively high levels of parental educational attainment. Parents also vary in their regulation of their children's media use, trying to maximize the advantages and to minimize the disadvantages and potential dangers (Livingstone, 2003; Livingstone \& Helsper, 2008). In addition, children with high potential in cognitive and meta-cognitive competencies profit more from possibilities to develop autonomously than their peers without these competencies (Overtoom, 1991; Baroody, 1993; Mooij, 1994; Byrne, 1998; Kalyuga, 2007).

Both personal and environmental characteristics contribute to the fact that, at the chronological age of about four, children differ in their levels of psychological development and performance, ranging between about two to seven years of age (Mooij, 2000; Hermanns, Öry, \& Schrijvers, 2005). This psychological diversity includes cognitive and emotional or expressive abilities and performance, and also meta-cognitive capacities to self-regulate 
playing and learning processes. The differentiation of personal and environmental characteristics and the interactions between them makes the exact specification or identification of personal characteristics a difficult task. Brown, Renzulli, Gubbins, Siegle, Zhang, and Chen (2005) conclude that various screenings or assessments based on various sources and points in time should be included to enable specification of personal characteristics to be promoted by home and education conditions.

In many European and other countries, developmental and educational processes in preschool or kindergarten and primary school are organised according to age and the corresponding tasks or activities are generally adapted to the mean age level of the children. This situation for example exists in Germany (Arbeitsgruppe Schulforschung, 1980; Händel, Vialle, \& Ziegler, 2013), the United Kingdom (Tymms, Merrel, \& Henderson, 2000; Wheadon, 2013; Norwich, Ylonen, \& Gwernan-Jones, 2014), the USA (Earle, 2001; Colangelo, Assouline, \& Gross, 2004; Lillard, 2012), and The Netherlands (Hermanns, 1979, 1980; Mooij, Roeleveld, Fettelaar, \& Ledoux, 2012). Generally, this implies that most of the tasks or activities fit most of the children in a group or class. For less-developed and highly-developed young children, however, the playing and learning activities that are offered do not fit their level of psychological development. Gagné (2011) interprets age-based education and grouping as the 'year/age lockstep' of educational systems around the world, causing many problems with learners.

This non-fit is responsible for many cognitive, social, emotional, behavioural, and motivational problems of children who function either clearly below or at a higher level than their age mates (Hermanns, 1979, 1980; Leseman, 2002; Bennett, Gordon, \& Edelmann, 2012; International Panel of Experts for Gifted Education (iPEGE), 2009). The more a child deviates from the group in, for example, cognitive and meta-cognitive respects, the more problems the child usually encounters in preschool (Kemp, 2000; Meijer, 2003; Mooij \& Driessen, 2008). This non-fit also implies that these marginal children are less able to selfregulate their activities in an appropriate, psychologically responsible way.

Pedagogically and psychologically education including information and communication technological (ICT) facilities should be adapted to and stimulate the development and learning of each child or learner (Parkhurst, 1922; Kohnstamm, 1928; Beirn, Kinsey, \& McGinn, 1972; Durkin, 1966; Kemp, 2000; Lubinski, 2004). Yet ICT-based pupil-monitoring systems for preschool and primary school in The Netherlands are characterised by pupils' age and class (Meijer, Ledoux, \& Elshof, 2011; Slinger, van Trijp, Verheijden, \& van Empelen, 2011; Nieveen \& Kuiper, 2012). Although many individualised ICT-based courses exist for arithmetic and language curriculum, for example, their content and diagnostic relevance in terms of the main ICT-based monitoring systems is not clear. Teachers not only have to carry out the bureaucratic operations required by the ICT of such monitoring systems, but also create developmentally and psychologically adequate learning situations for the marginal pupils. This involves working out separate, and more detailed, specifications for each pupil who does not fit the mean level. Moreover, as the monitoring systems generally do not integrate playing and learning content and their evaluations in one integrated system, for each marginal child, teachers have to discover, or guess, which content is evaluated by which aspects of the monitoring system (Mooij, 2008, 2009; Meijer et al., 2011). Comparable 
problems exist in the other countries as mentioned above (Earle, 2001; Betebenner, 2009; Händel et al., 2013; Wheadon, 2013).

It therefore seems that ICT-based pupil-monitoring systems are designed to reproduce traditional school practice, including the well-known problems associated with this practice for pupils deviating from the mean in each class. Such ICT design increases the teachers' work instead of facilitating it, as was the original claim made when introducing ICT in education (Ely, 1999; Sinko \& Lehtinen, 1999; Kemp, 2000; Mooij \& Smeets, 2001; Watkins, 2001; Mooij, 2004, 2006). Integration of ICT in adequately differentiated playing and learning processes could assist teachers and pupils in preschool and primary school, but the required systematic ICT support does not seem to be developed yet.

This ICT burden for teachers can be overcome by building upon pedagogical, psychological, motivational, and didactic characteristics aimed at creating relatively optimal educational levels for each pupil throughout preschool, primary school, and beyond. The proposed design of this approach integrates theoretical and practical aspects of education and learning that are applicable across time and place, as evident in, for example, Parkhurst (1922), Kohnstamm (1928), Durkin (1966), de Groot (1966), Arbeitsgruppe Schulforschung (1980), Heckhausen (1980), Collier (1994), Bergqvist and Säljö (1998), Sinko and Lehtinen (1999), Brush and Saye (2001), Gustafson (2002), Mooij (2002, 2007a), Colangelo et al. (2004), Andrade (this issue), Cebrián Robles, Serrano Angulo, and Cebrián de la Serna (this issue), Raposo Rivas, Cebrián de la Serna, and Martínez-Figueira (this issue), and Steffens (2006, this issue). The research question therefore asks for the identification and structuring of pedagogical-didactic, organisational, and ICT characteristics that, in combination, can be expected to promote diagnostically adequate, flexible playing and learning processes for each pupil; moreover, pupils who are able to self-regulate their learning to some degree should be enabled and stimulated to do so, whereas pupils who need more teacher assistance should receive this support. This type of research fits Model 3 of ICT-based learning as indicated by Mooij, Steffens, and Andrade (this issue); see also Banyard, Underwood, and Twiner (2006) and Carneiro (2006).

To answer this research question, we will first sketch a theoretical framework in which specific education and ICT conditions are hypothesised to optimally support playing and learning processes as well as differing degrees of self-regulation for pupils in preschool or primary school. We will furthermore provide results of a pilot study to screen beginning characteristics of pupils and sketch some main aspects of a randomised intervention study conducted in integrated Dutch preschools/primary schools for pupils aged $4-12$. Finally, we will discuss possibilities for integrating this type of research into comprehensive European research.

\section{Theoretical Framework}

\section{Learning Differences, Class Organisation, and Self-regulation of Pupils’ Learning}

A primary goal in preschool or kindergarten is to socially integrate children by forming groups and involving them in enjoyable educational activities. To realise this goal, children are typically grouped according to age. Whether or not some of the children are 
underchallenged cognitively, for example, while others are overchallenged, depends on the degree to which play and learning curricula and the related level of self-regulation are differentiated (Mooij, 1992; Jewett, Tertell, King-Taylor, Parker, Tertell, \& Orr, 1998; Skinner, Bryant, Coffman, \& Campbell, 1998; Lubinski, 2004; Lillard, 2012).

Diagnostically adequate differentiation including self-regulation at the beginning of preschool does not seem to be self-evident, however (Bennathan \& Boxall, 1996; Lems, 1996; Purcell, Burns, Tomlinson, Imbeau, \& Martin, 2002; Colangelo et al., 2004; The Scottish Government, 2009). In age-based schooling, cognitive and meta-cognitive development and stimulation are important in the playing processes and the curriculum, next to attention for pupils' social, emotional, and senso-motor functioning. The degree of educational differentiation of a school is then conditional on the adequate stimulation and motivation of pupils who are marginal when compared to the mean of their age group. Both cognitive underchallenge and overchallenge will reduce, or prevent, the adequate growth of the children in various domains and their capacities to learn how to manage or self-regulate their own development and learning (Parkhurst, 1922; Bowerman, 1978; Zimmerman, 2000, 2002). This is also demonstrated in research concentrating on scaffolding in teacher-pupil interaction (van de Pol, Volman, \& Beishuizen, 2010) and in effects of school-based programs for increasing pupils' connectedness and reducing their risk behaviour (Chapman, Buckley, Sheehan, \& Shochet, 2013).

According to Zimmerman (1990), self-regulated learning (SRL) is characterized by pupils' use of specific learning strategies, responsiveness to self-oriented feedback about learning effectiveness, and interdependence of motivational processes and SRL. SRL learning strategies and theories concentrate on how learners select, organize, or create challenging learning environments for themselves and on how these learners plan and control the form and amount of instruction. Compared to other learners, "self-regulated students are distinguished by their systematic use of metacognitive, motivational, and behavioral strategies; by their responsiveness to feedback regarding the effectiveness of their learning; and by their selfperceptions of academic accomplishment" (Zimmerman, 1990, p. 14). Moreover, Zimmerman (1990) emphasizes that metacognitive, motivational, and behavioural strategies should be integrated in school instruction to affect long-term effects (see also Heckhausen, 1980).

Therefore, to support the growth of SRL and increase motivation, identifying the actual learning level of each pupil is essential at the start of preschool. Based on this diagnosis, instruction and digital support should differentiate playing and learning tasks and classroom organisation structures, to accommodate diverse ability levels and learning strategies. Teachers should also focus on ways to differentiate classroom activities and processes to further develop self-regulation (Perels, Gürtler, \& Schmitz, 2005). It is expected that development and learning will increase as pupils are allowed to take more initiative and responsibility within a coherent pedagogical and instructional structure (see also Parkhurst, 1922; Zimmerman, 2002; Rozendaal, Minnaert, \& Boekaerts, 2005; Lillard, 2012).

\section{Diagnostically and Instructionally Adequate Curricula}

At the pupil's level, differentiated SRL can be expressed in learning cycles characterised by (1) estimating the difficulty level of learning tasks in a specific competence domain, followed 
by selection of the tasks to be performed; (2) selecting types of support, or intensity of support, for carrying out the learning tasks; and (3) assessing the effectiveness of the learning according to specific criteria or norms followed by applying the results in the design of followup tasks (Bowerman, 1978; Mooij, 2007a). Increasing a child's self-regulation or 'learner control' by providing fitting support or scaffolding is a necessary condition for increasing motivation and effectiveness on subsequent learning tasks (Parkhurst, 1922; Brush \& Saye, 2001; Mooij, 2007b).

A learning cycle consists of integrated diagnostic, instructional, managerial, and systemic aspects of the development or learning processes in a preschool or other type of educational institute. A structured set of play or learning tasks forms an 'instructional line', which may be one of many sets of instructional lines. Combining these lines results in 'learning arrangements' which build a specific curriculum or curriculum part. An instructional line, for example, starts with one or more diagnostic tasks, tests, or indicators which serve as a criterion indicator referring to a specific content and specific level of curricular activities to be performed; a diagnostic indicator that refers to a score representing a standardised or nationally representative value is based on normed assessment (Kemp, 2000; Earle, 2001; Betebenner, 2009; Mooij, Haverkort, \& de Kleijne, 2013; Wheadon, 2013). A diagnostic indicator which is, or can be, used as both a criterion indicator and normed assessment simultaneously defines a task or test representing 'double diagnostics' (Mooij, 2007a, 2007b, 2013).

Integration of criterion-based, norm-based, and double-diagnostic indicators in instructional lines will secure coherent and multiperspective differentiation, evaluation, and instructional support to promote continuous learning progress at individual, small group and class, and school levels. The combination of the most relevant curricular concepts and their diagnostic assessments, whether criterion-based, standardised or norm-based, or double diagnostically based, specifies an instructional 'pedagogical-didactic kernel structure' (PDKS) of competence domains referring to a specific level of attainment in the national educational system (Mooij, 2007b, 2013) or at international comparative level.

Furthermore, the diagnostic and instructional aspects of the learning processes must be managed adequately to organise and evaluate subsequent learning processes for individual pupils and small groups of pupils (Kreijns, Kirschner, \& Jochems, 2003; van den Boom, Paas, van Merriënboer, \& van Gog, 2004), whole groups or classes, schools, or higher organisational levels. Here ICT can give support by integrating educational, diagnostic, and instructional characteristics on the one hand, and information about individual, small group, and class learning progress on the other. The managerial aim is to achieve multilevel transparency and an optimal balance expressed in both individual and group-based learning progress, given the pedagogical choices made and the budgets available.

The systemic aspect of learning indicates that a pupil not only belongs to one or more small groups or classes in preschool where he or she spends many hours every week, but also to a family and one or more peer groups outside school. Moreover, a pupil at risk may also have contacts or learning experiences with youth health-care professionals, for example. ICT can be designed to integrate information and support the pupil's development across these different environments (Hermanns et al., 2005; Black, McCormick, James, \& Pedder, 2006; James, Black, McCormick, Pedder, \& William, 2006; Mooij, 2009). 


\section{Three Conditional Dimensions}

Differentiation of learning materials and procedures, integration and use of ICT support, and strategies to improve development and learning, can therefore act as related educational conditional dimensions referring to diagnostic, instructional, managerial, and systemic aspects of learning. This theoretical framework is sketched in Table I. The table illustrates that the combination of the three dimensions and the four aspects results in a pattern of 15 guidelines, to realise optimal education and conditions for optimal development and learning.

\section{Insert Table I about here}

The first dimension in Table I concerns differentiation of curricular materials and procedures, using instructional lines including double diagnostics, if possible. The curricular materials form learning blocks that can be used by specific categories of pupils; a compilation of blocks across levels of attainment represents a school career. Guidelines 1.1-1.5 specify the pedagogical-didactic kernel structure (PDKS) referring to competence domains, the most important curricular concepts, and assessment from a double diagnostic point of view. The domains may, for example, specify social-emotional performance; general intelligence; language; arithmetic/mathematics; physical-medical aspects; general psychological characteristics; or motor activities (Gallagher, 1975; Byrne, 1998). The diagnostic indicators must be related to sets of playing or learning tasks and other curricular activities in school practice, to build instructional lines concerning optimally differentiated and self- regulated playing and learning arrangements for various types of pupils.

Internet-based ICT can assist in registering, integrating, evaluating, and reporting learning processes across various types of learning situations and organisational levels (Crook, 1998; Clark \& Estes, 1999; Blumenfeld, Fishman, Kraycik, Marx, \& Soloway, 2000; Watkins, 2001; Meijer, 2003; Walsh, Hodge, Bowes, \& Kemp, 2010). Guidelines 2.1-2.5 of Table I therefore require the development and use of specific Internet-based ICT to support and empower guidelines 1.1-1.5. If this ICT supports the various diagnostic, instructional, managerial, and systemic learning aspects referred to in the theoretical framework, ICT is the second conditional dimension for optimal education and optimal learning (Sinko \& Lehtinen, 1999; Kemp, 2000; Earle, 2001; Mooij, 2002, 2009). Digital opportunities for a teacher, pupil, or small group of pupils to didactically clarify or self-regulate the next learning steps can be based on double-diagnostic, PDKS-related learning lines. In this way, improvement of selfregulated learning is expected to be realised much better than is possible with norm-based pupil monitoring.

In school practice, the first and second conditional dimension can be empowered by a third dimension with a focus on conditional strategies to improve each pupil's development and learning, including the self-regulation of learning. Guidelines 3.1-3.5 in Table I concern the screening of a pupil's initial or entry-level characteristics in preschool (see also Durkin, 1966; Mooij, 2000; Colangelo et al., 2004). The results indicate level-adequate play materials, or appropriate instructional lines and sublines, as a starting place for an individual child (Bennathan \& Boxall, 1996; Lems, 1996; Tymms et al., 2000; Reynolds, 2005; Lillard, 2012). Collaborative social and didactic procedures can further stimulate pupils' prosocial learning in 
a small group context (cf. Hepler, 1998; Kreijns et al., 2003; Chen, 2006; Mooij \& Smeets, 2009). Instructional support should differ among pupils in accordance with their levels or competences, magnitude of learning steps, use of meta-cognitive strategies, and level of selfregulation during learning. Managerially, collaborative self-regulation of pupils in small groups enables the teacher to concentrate more on those pupils most in need of coaching.

The theoretical framework in Table I emphasises diagnostically adequate differentiation and appropriate placement concerning play and learning processes, learning arrangements and extra projects, and self-regulation, beginning with a pupil's very first day in preschool. This means, for example, that four-year-old pupils, who function at language or maths levels of sixor seven-year-old pupils, are enabled to function at or above their actual performance level, even if these pupils are placed in their age group. Such cognitively gifted pupils are marginal pupils (about $10 \%$ of their age group) who score relatively highest as diagnosed with cognitive screening results as estimated by their infant day-care centre, parent(s), or preschool teacher; as identified with a personality test; or with national pupil monitoring tests in cognitive achievement (see also Brown et al., 2005; Gagné, 2011). Their appropriate placement in the curriculum and consequent educational stimulation will have positive effects on their cognitive, social, emotional, and motivational performances (Durkin, 1966; Heckhausen, 1980; Mooij, 1999; Bailey et al., 2012; Sontag, Stoeger, \& Harder, 2012). Comparable but different pedagogical and curricular content and procedures are necessary for pupils who lag behind in one way or another (Bennathan \& Boxall, 1996; Mooij, 2000, 2013; Bennett et al., 2012).

\section{Hypothesis}

If relatively advanced pupils have access to PDKS-differentiated instruction at specified levels appropriate to their initial competence, they can effectively engage in instructionally supported and self-regulated learning processes at their own levels. Analogously, the same is true for pupils developing relatively more slowly than their age mates. Once this type of educational differentiation becomes school practice, the traditional, age-based preschool and primary school system transforms into an instructionally supportive, PDKS- and ICT-based managerial system which meets the needs of different pupils in a relatively optimal manner. The transformation will improve the learning processes and educational careers of both relatively high- and relatively low-ability pupils (Mooij, 2013). A multilevel hypothesis to express this transformational expectation is:

As differentiation of learning materials and procedures (dimension 1), integration by and use of ICT support (dimension 2), and strategies to improve development and learning (dimension 3) are achieved at multiple educational levels in preschool and primary school, multilevel differentiation and evaluation of learning processes will improve. This will result in better self-regulation and higher social, emotional, motivational, and cognitive learning outcomes for pupils who initially deviate the most from the mean in their group or class, or their peers' norm.

\section{Method}


As the research was conducted in The Netherlands, we will first provide some information about the Dutch education system. Between 0 and 4 years, children may attend an infant daycare centre, in particular when both parents have a job. Next, almost all children attend a preschool from when they turn four. In preschool, pupils are usually organised according to age, with only minimal exceptions (Mooij, Hoogeveen, Driessen, van Hell, \& Verhoeven, 2007; Doolaard \& Oudbier, 2010; Driessen, 2013). Preschool (two years of education) is formally integrated with primary school (six years of pupils, or 'special education' for pupils characterised by specific psychological or physical disabilities. Standard national or regional curricula or learning requirements do not exist, however, because this would be in conflict with the legally defined responsibility of schools. Yet schools are legally obliged to provide educational services characterised by continuous individual progress for all pupils. When pupils are about twelve years old they attend secondary education, which has four regular tracks that are differentiated with respect to educational attainment. The situation concerning the lack of a standard national curricula is comparable to that in preschool or primary education. This is also true for higher levels of education. This system leaves much responsibility for schools, but it does not seem to simplify matters for schools.

The main Dutch national pupil-monitoring system for preschool and primary school is characterised by age- and class-based organisation of pupils (Meijer et al., 2011; Nieveen \& Kuiper, 2012). This ICT-based system provides various types of achievement tests. Schools are not obliged to use this system, but most of them do. For each participating pupil, the system can provide the pupil's standard or norm-based scores based on the age of peers; in addition, the monitor provides individual information about the degree to which the pupil deviates from his or her peers. Teachers can use both types of information to structure their teaching, but only the norm-based scores match the school curricular methods and educational support books and materials for a specific age. Adaptation to individual pupil score profiles requires extra work for teachers.

It should be added that general formulations exist for desirable learning goals to be realised for specific ages. However, there is no clear or univocal relationship among the general learning goals, the various curricular methods, and the various learning concepts or attainment levels in the national pupil monitoring system. This lack of transparency has legal and political roots, but from pedagogical and psychological points of view it is a main problem in Dutch schools and also presents challenges to the work of the Education Inspectorate, which is the official body that looks after school quality and oversees school achievement (Mooij et al., 2012). To bring more clarity in the relationships between educational and learning processes, and to reduce the related problems of teachers, parents, and marginal pupils in particular, we can use the guidelines of Table 1 including the concept of 'double diagnostics' (see the theoretical framework).

\section{Two Research Steps}

The framework in Table I can be used as a tentative design for researchers to collaborate with teachers in schools in order to innovate and improve schooling for pupils who are identified as functioning relatively marginally compared to other pupils in class. In line with Cobb, 
Confrey, diSessa, Lehrer, and Schauble (2003), this method is considered a 'design experiment' (see also van den Akker, Maribe Branch, Gustafson, Nieveen, \& Plomp, 1999). An important advantage of this in-service development is the opportunity to evaluate the school relevance, or ecological validity, of the guidelines in Table I. Preliminary experiences in the schools have clarified that preschool and primary school teachers and principals need much support to realise the necessary transformation of their school including the learning processes (Mooij, 2007a, 2009, 2010). Usually, focusing on marginal children and their problems in the first year of preschool offers a starting point for teachers to analyse the causes and take the consequences seriously in their own practice. A first research step, then, requires the estimation of the beginning characteristics of each incoming child in preschool (guideline 3.1 in Table I).

A second, more comprehensive research issue is to use the beginning characteristics as a starting point to realise appropriate placement of the pupil in the main instructional lines. Teachers first need to develop or order adequate instructional lines, including criterion-based and norm-based curriculum activities in small groups and classes, and also include free play or other types of self-chosen stimulating and challenging activities. In addition, at the school level, school-specific didactic and managerial aspects concern the integration or continuity of instruction and learning across classes in preschool and into primary school; stimulation of opportunities for even the youngest pupils to self-regulate their playing and learning regarding content and organization; and stimulation and mutual control of prosocial relationships among pupils in small groups in particular (see Table I). This second research step is included in a randomised intervention study in preschool to assist the development of differentiated optimal education as outlined above and to check the effects on the pupils.

\section{Step 1: Pilot Study on Screening of Beginning Characteristics}

The first research step was to pilot the screening of pupils' beginning characteristics. This took place between 2008 and 2010. The goal was to develop, implement, and review the whole procedure in practice in the context of the guidelines in Table I. The pilot school is an integrated preschool-primary school that was selected because of its collaboration with infant day-care teachers. The school building is located in the eastern part of The Netherlands ('preschool East')

A psychometrically controlled screening instrument was developed for this longitudinal research involving 966 children who were about four years old (Mooij, 2000). To implement the use of this instrument, an infant day-care teacher, the parents, and the preschool teacher first complete a questionnaire to estimate a child's level of competence in seven domains by comparing the child's behaviour with the behaviour of same-age peers. The seven scales refer to social interaction / communication, general cognition, language proficiency, preliminary arithmetic, senso-motor level, emotional-expressive level, and expected educational behaviour / motivation of the child in preschool (Alpha scale reliabilities for parents vary between .65 and .92; for teachers between .75 and .91). The questionnaire can be administered by an infant day-care teacher and by the parents when a child is about to go to preschool; the preschool teacher can complete the questionnaire after the child's first month in preschool. 
Furthermore, about six weeks after a child has entered preschool, the preschool teacher and the parent(s) meet to discuss each other's screening results and reflect about the next educational, diagnostic, or instructional steps. Parent(s) or care-giver(s) and the teacher may differ in their screening of specific characteristics of the same child, but here it may also be relevant that the home situation and class situation differ. The aim of the screening procedure is to bring parent(s) and teacher together and combine their expertise about the child to construct a mutually trusted way to promote the preschool experiences of the child. The common goal is to realise appropriate placement for the child in clearly structured development and learning processes, characterised by double diagnosis in important developmental or curricular domains, within two months of admission. Screening results are only one type of indicator and should not be taken as absolute (see also Brown et al., 2005). In the results section, we will present some qualitative and quantitative information about the screening procedure. The quantitative information consists of descriptive statistics, reliability coefficients (Alpha), paired t-tests, and Pearson Correlations.

\section{Step 2: Randomised Intervention Study in Preschool}

Operationalisation of a concept PDKS and ICT. According to Table I, the necessary differentiation of education first of all requires the development of a pedagogical-didactic kernel structure (PDKS). An initial inventory of Dutch youth health tests and pupil-monitoring instruments resulted in a prototype set of hierarchically structured competence domains concerning language, arithmetic / mathematics, general cognition, social-emotional performance, physical-medical aspects, general psychological characteristics, and motor activities (Mooij, 2007a, 2009). The concepts and subconcepts per domain tap curricula for children aged $2-12$ and can aid diagnosing or evaluating psychometrically valid criterion and norm indicators.

The next activity was to develop ICT to assist the use of the prototype PDKS in preschools and to promote the development of instructional lines in the curriculum. ICT development started by designing Internet-based support for the PDKS, according to guidelines 2.1 - 2.5 in Table I (Mooij, 2007b, 2009). Teachers, pupils, parents, and other professionals can use but not change the normed basis of the PDKS. However, within a school it is possible to attribute criterion-based curricular or other learning information to normed national tests. For example, a teacher can apply test information at the national level to select one or more (sub)concepts referring to specific skills assessed by a pupil-monitoring test and digitally connect criterion-based curricular tasks or school-based evaluation activities to digitally self-made instructional lines. This combination results in specific digital learning arrangements for specific types of pupils. Learning arrangements can also be stored by the software prototype and be assigned to any pupil or small group of pupils, or be changed whenever desired. Moreover, schools can decide to collaborate with any other school and exchange digital learning objects or arrangements via the Internet. Finally, a digital procedure to estimate the beginning characteristics of a child by parents and teacher was created (Mooij, 2009; Dijkstra \& Mooij, 2012). 
Design. A randomised field experiment entitled "Excel Kwadraat" was chosen to implement the screening and the PDKS-based differentiation including ICT in preschool and to check the hypothesised effects with pupils. The research is in progress in Dutch integrated pre- and primary schools, starting in 2011 and continuing until 2015. The research focus is to intervene in schools in order to start the comprehensive innovation by schools of the educational dimensions outlined in Table I. The design used is a pre-intermediate-post-test, while assessments concentrated on the school, class, and pupil level in 2011, 2012 and 2013. The hypothesised cognitive, social, emotional, and motivational effects on the pupils are measured with a multilevel longitudinal design.

Intervention. The whole-school intervention starts with the implementation of the screening procedure, which is followed by in-service training and development of a concept PDKS with the teachers; then actual changes of didactic and organisation characteristics in preschool (years 1-2) are planned, followed by application of these changes with marginal pupils. Given the urgency to improve Dutch education, the focus is on curricular development for cognitively gifted pupils (see the definition in the theoretical section). In-service training is conducted per preschool or small group of preschools, about four times a year. The main implementation features are: 1) screening procedure to identify beginning characteristics; 2) development of PDKS-based differentiation in (preliminary) arithmetic; 3) development of PDKS-based differentiation in language; 4) development of a school policy and protocol for handling cognitively gifted pupils. The researchers evaluate the implementation process characteristics per preschool by making field notes and assessing the implementation results per year. Moreover, school principals and teachers complete evaluation questionnaires. The degree of implementation per preschool is conditional on financial compensation; participating preschools get a maximum of $€ 3,300.00$ for their collaboration.

\section{Results}

Pilot Study: Screening of Beginning Characteristics

Introduction. Preschool East can be characterised as child-friendly and development-oriented ( $\mathrm{N}$ pupils about 400). The school was initiated in 2001, in a region where a new suburb was planned. The mean education level of the parents is quite high. The school differentiates instruction of playing and learning processes into a variation of levels such as the individual pupil, a small group, a class, and a unit; a unit is a specific part of the school building where about 100 pupils reside who are all in years $1-8$. Several meetings among the first author, the most involved teachers, and the principal were organized to clarify use of the procedure. The school decided to use the complete procedure with all new four-year-olds and those who were almost four. The school also wrote a concept paper including all aspects of the procedure and its use in its own context. Whenever a new child had attended an infant day-care centre, the teacher from this centre was also asked to complete the screening questionnaire.

Implementation. During each of the implementation years from 2008 - 2010, the first author had about three communication sessions with the principal or one or more of the teachers to 
discuss experiences and coach the desired usage with respect to the screening procedure and the various results. Parents and teachers in particular exchanged particularities of each new pupil and the potential pedagogical and psychological consequences were integrated in various playing and curriculum situations, or included in activities for a small group of children. If deemed necessary, preschool teachers contacted the infant day-care centre for more information, applied further diagnostics, or integrated the support of for example youth health care professionals. Teachers discussed the information with the child's parents to integrate new insights or to implement additional teaching approaches or materials.

Evaluation. On the whole, the teachers and principal evaluated the screening procedure and the related collaboration with care-givers or parents very positively and decided to continue the use of the procedure. However, the teachers were reluctant to implement follow-up differentiation in teaching. Generally, each unit's playing and learning materials are ordered and made available on shelves so that even the youngest children can easily access and return them, which is a positive factor for self-regulation. But for individual pupils the range of across-year or extra activities remained restricted, mainly because teachers did not feel comfortable about allowing pupils to use them. If they should do so, they would surpass or change the existing organisation of the school; moreover, the very good or excellent pupils would progress quickly and be ready for secondary school earlier than they should.

Quantitative results of the screening. Table II presents the reliability coefficients (Cronbach's Alpha coefficients) and the number of items used per scale, separately for three respondent groups (infant day-care centres, parents or care-givers, preschools). Moreover, comparable results obtained in nationally representative, normed research are presented (see Mooij, 2000). Reliability results obtained in preschool East can be characterised as good; they also correspond to the results of the normative study.

\section{Insert Table II about here}

Further information on means and standard deviations of the scale scores in preschool East, per respondent category, is given in Table III. Statistical differences between the mean scores are tested by paired t-tests. The results are given in Table IV. Means can differ slightly between Tables III and IV because, in Table IV, paired comparisons may be based on different numbers of informants per group (day-care, parents, preschool) as not all informants had screened each pupil.

Insert Table III about here

Insert Table IV about here

The results in Table IV indicate that the mean scale scores of teachers in day-care centres and the parents generally agree; the means differ only with respect to senso-motor level. In this respect, teachers in day-care centres score young children higher than do the parents of these children. In comparing day-care centres and preschools, day-care centres score the children higher on senso-motor level, and lower on pre-arithmetic level. Most differences occur 
between the scoring of the parents and the preschool. Preschool teachers score the children higher than the parents do on social-communicative level, pre-arithmetic level, senso-motor level, and expected educational behaviour or motivation for school. As indicated above, these results should not be interpreted in an absolute way, but as indicators to support each pupil in starting a relatively optimal school career.

Final exploration occurs by calculating Pearson Correlation coefficients between the scale scores per informant group: see Table V. Generally, relationships between the scale scores of teachers of infant day-care centres are relatively highest; preschool teachers are next, and the parents demonstrate the relatively lowest covariation between their scale scores. These patterns globally imply that, compared to the teachers, parents perceive relatively more differences in the level of development among the children.

Insert Table V about here

\section{Randomised Experiment}

Development and implementation in practice. Like preschool East, most Dutch preschools keep most of the pupils' playing and learning materials on shelves distributed throughout the classroom, along the walls, or in the corridors. Pupils may get these materials on their own initiative, at specific times, or because of an assignment by the teacher who may want to promote some pedagogical or instructional criterion. In regular preschools the ordering of these materials is generally not according to the specific domain or level of development.

Conforming to the guidelines in Table I, the materials should be ordered with respect to content such as arithmetic, language, senso-motor development, and so on. Moreover, within each domain, the level of difficulty should be transparent in practice, and for pupils. Relevant materials have to be specified with respect to developmental concepts, instructional lines, and PDKS-based ability levels or tests used for the first half of the first year according to the national pupil-monitoring system, the second half of the first year, the first half of the second year, and so on. Such prepared playing- learning situations enable small groups of pupils or individual pupils to use the materials and instructions independent of their age.

In addition to the use of the screening procedure, then, the experimental preschoolprimary schools had the task of developing and using a first version of a PDKS-based educational ordering of their playing and learning materials in years $1-3$. Researchers coached this development by meeting about four times a year with each school team or small group of teams; introducing a newsletter for all schools; and communicating on demand by email or telephone. An example of an intervention result is a set of shelves with materials ordered by an experimental school in the course of the first intervention year: see Figure 1. The picture also illustrates that teachers use different colours and icons or other symbols on each of the shelves to indicate the ordering of contents and levels, thus representing ordering and integration of playing and learning materials for preschool years 1 and 2, and primary school year 3, for example.

Insert Figure 1 about here 
Within a vertical shelf compartment for a particular domain, materials can be organised according to level of difficulty into easy (upper shelf), medium (middle), and challenging (lower shelf): see Figure 1. The registration system used to indicate the materials and the individual progress of pupils usually differs among schools. The reason is that Dutch schools generally can, and want, to integrate various playing and learning materials based on their own preferences and priorities in school. In the context of the intervention this differentiation is acceptable as long as the principle of double diagnostics is used as the underlying structure for the ordering. The PDKS is used to enable a general feature from which schools can select; schools themselves can integrate school-specific criterion-based concepts and assessments, if desired.

The resulting differentiated educational system in school has to be clear for both teachers and pupils to allow prepared instruction and stimulate the pupils' self-regulation and self-management. Although not obliged, some experimental schools want to go far in developing their own registration system. Continuation of the ordering of PDKS-based materials and selected other materials across subsequent school years enables unlocking of the year/age lockstep (cf. Gagné, 2011): see the picture of pupils of different ages working on the same task in Figure 2.

Insert Figure 2 about here

Two Montessori (pre)schools were included in the study. In these Montessori preschools, the intervention revealed that criterion-based concepts and the corresponding instructional lines are quite clear beforehand. However, the schools do not know the relationships of their educational system with the attainment level of the national pupil-monitoring system. The relevance is that, from a criterion point of view, pupils in Montessori preschools can function at much higher or lower levels than required from a normed pupil-monitoring point of view. One result from coaching these Montessori teachers is that they are surprised to find that some of their pupils in year 1 actually function at year 4 normed level, or pupils in year 5 are functioning at the highest level of year 8 in primary school. This diversity is explained by the fact that, according to Montessori pedagogy and teachers' supervision strategy, pupils can self-regulate their playing and learning activities to a very high degree (see also Lillard, 2012). An example is presented in the picture in Figure 3 where pupils in Montessori preschool years 1 and 2 collaborate successfully in doing arithmetic tasks for year 6 in primary school.

Insert Figure 3 about here

Of course, pupils will always need the teacher, but for different pupils this support is needed for different types of activities and to varying degrees. Pupils with special educational needs usually require much more attention at lower levels than pupils who achieve highly from cognitive and meta-cognitive points of view. An illustration of free activities by this last category of preschool pupils, featuring posters they made to present to their class, is given in Figure 4.

Insert Figure 4 about here 
The role of ICT. Initially, the ICT prototype was introduced in experimental preschools in combination with the main intervention features. The aim was to facilitate the development and implementation of the differentiated preschool programme, but soon it became clear that this did not work as hoped. Teachers and principals needed much clarification and examples of the new concepts and work procedures in their own schools, which had to occur while their traditional programme was also functioning. In this respect, huge school-specific differences in innovation capacity and flexibility were noticed among experimental preschools. Moreover, preschools became more sensitive to the issue of diagnostically based curricula and their efficient organisation, but instead of the new ICT prototype they preferred the traditional ICTbased pupil monitoring system because of its wide distribution, national applicability, Education Inspectorate's use of it to evaluate school achievement in a national oversight process, and its reputation. To eliminate such discussions, and to better concentrate on the essence of the school innovation, it was therefore decided to reduce the attention on ICT and focus instead on the pedagogical, didactic, and organisational features of the intervention.

Case study. One example concerning one child in an intervention school illustrates what may happen when 'optimal education' is underway. Lorette (pseudonym) is a new four-year-old girl in an experimental preschool. Before entering preschool, the parents screened the beginning or baseline characteristics of their daughter. The parents perceived their child as being average on social and senso-motor behaviour; expressive behaviour and expectations about school behaviour are above average; and general cognitive, language, and arithmetic abilities are scored at the highest level (compared to age mates). After four weeks in preschool, the teacher is of the opinion that the social and senso-motor behaviour of Lorette are at an average level; language and expressive behaviour are above average; and general cognitive level, arithmetic level, and expectations about school behaviour are at the highest level.

After six weeks in preschool year 1, parents and teacher meet to discuss their estimates. A summary of the meeting results made by the teacher illustrates that Lorette is perceived to be very sensitive, with pertinent ideas about how things should go, and very eager to know and learn. The first weeks in preschool were not easy for her, however, because she wanted to know beforehand what would happen. Emotionally, things went better after she found a friend in class. She is perceived to be smart and to function cognitively at high levels, but is not yet demonstrating her full capacity because in preschool specific senso-motor facilities are required. In particular, her motor capacities are not developed sufficiently to enable paper-andpencil testing as required now and then. Observation by her teacher, and oral checks by using nationwide pupil monitoring tests, verify that Lorette functions cognitively at levels of year 2 or higher. Lorette knows how to count and knows numbers and letters. At home she demonstrates still greater and higher cognitive advancement; at preschool the understanding and getting along with the complex social situation still requires much of her. Results of norm-based pupil monitor tests demonstrate her functioning in language at the highest level (A) of year 2 (for pupils who are one year older); in arithmetic she functions at a high level (B), year 2. Parents and teacher agree that Lorette will carry out activities and materials at these levels by using the newly developed shelves with PDKS ordered learning materials. An appointment is made between teacher and parents to continue the observations and checks at preschool and the observations at home. The next meeting will be held before the summer holidays. 
After these holidays, the teacher indicates that Lorette's functioning has much improved both socially and cognitively. She now uses learning materials at year 3 level, usually works with one or more other advanced pupils in a small group, and is motivated to apply selfregulation behaviours in free activities. Moreover, preschool and primary school discuss continuing the preparation of the shelves with ordered learning materials to integrate the advanced pupils into the primary school.

\section{Discussion}

Pedagogically and psychologically, learning, and in particular SRL, should be based on differentiated instruction at or above the actual level of development of each learner, whereas ICT should enhance the self-regulation and administration of learning progress. To realise such a situation, a theoretical framework was sketched in which pedagogical-didactical, organisational, and ICT conditions were hypothesised to support diagnostically-based learning processes for each learner (see Table I). To check the theoretical approach in practice, design-based development was planned in Dutch (pre)schools.

\section{Summary}

Pilot study on screening of beginning characteristics. The first research step was a pilot study focused on the estimation of beginning or baseline characteristics of all new four-year old pupils in preschool East. Screening occurred with respect to seven developmental areas using a psychometrically checked questionnaire. Discussion of the results between parents and the preschool teacher aimed to increase the validity of the estimation, the construction of a trustworthy relationship between home and preschool, and the foundation of next diagnostic or other educational activities for each pupil. The reliabilities (Cronbach's Alpha coefficients) of the scale results vary between 'sufficient' (.62) and 'good' (.97) for parents; for preschool teachers and infant day-care centre teachers these coefficients are 'good' $(.81-.97)$.

Compared to the teachers, parents discriminate relatively most regarding the entry characteristics of their children. It is interesting to note that preschool teachers screen children relatively higher than the parents do, which suggests a relatively modest claim from the parents concerning the developmental levels of their children.

Furthermore, implementation of the screening procedure was realised as proposed. After getting used to the procedure, the preschool teachers and the principal evaluated the screening procedure as positive. However, for children functioning above age level the range of acrossyear or extra activities was restricted because teachers did not feel comfortable enabling children to do more, as this would change the school organisation and the pupils would leave school earlier than usual.

Experimental intervention in regular preschool-primary schools. The second research step therefore concentrated on the use of the screening procedure in the context of diagnosticallybased playing and learning instructional lines and materials across years, being available beforehand. This research step consists of a randomised experiment "Excel Kwadraat" including intervention conforming to a longitudinal multilevel design in 37 Dutch integrated 
preschool-primary schools. Essential to the intervention are the school-based construction of main instructional lines including PDKS-related criterion-based, norm-based and double diagnostically based curriculum activities or materials; differentiation between curriculum activities and free play or other types of self- chosen activities; and development of ICT to support this type of optimal education (see Table I). In the in-service intervention, the researchers assist the ordering of curricular and other materials by teachers according to criterion- and norm-based assessment, if possible. The ordered materials are organised on shelves. Teachers use different colours and icons or other symbols to indicate the ordering of specific content and levels, thus representing integration of playing and learning materials for preschool years 1 and 2, and primary school year 3. Children can use these instructional situations in various self-regulated ways (see Figures $1-4$ ).

Further research with respect to this randomised experiment is organised as follows. First attention is given to potential improvement of the empirical foundations of the theoretical modelling as given in this article. To realise this goal, a systematic review of 114 peerreviewed studies published since 1990 reporting original empirical research is carried out to explain the causes and effects of academic underachievement of cognitively gifted pupils and provide an overview of interventions and results (Dijkstra, Walraven, Mooij, \& Kirschner, submitted a). A second study concentrates on the intervention as conducted in kindergarten practice. It focuses on teachers' implementation of differentiated instruction for high-ability or cognitively gifted children, in particular on their perceptions of factors affecting the success or blocking of this educational innovation (Dijkstra, Walraven, Mooij, \& Kirschner, in preparation a). A third study investigates the longitudinal, quantitative effects of the intervention. Does the intervention, as hypothesized, improve the educational differentiation as perceived and handled by the kindergarten teachers in their practice (Dijkstra, Walraven, Mooij, \& Kirschner, in preparation b)? Final attention is given to the effectiveness of the integrated in-school intervention with respect to the kindergarten children. It is expected that, by affecting kindergarten teachers' differentiation practices, the intervention also affects the cognitive and socio-emotional development of (initially) excellent and non-excellent kindergarten children (Dijkstra, Walraven, Mooij, \& Kirschner, submitted b). Taken together, these studies will provide a first comprehensive, empirical check of the theorising in this article.

\section{Further School Development in a European Context}

The research informs the development of optimal education and its possible effects on young pupils in a Dutch context. Some of the development experiences are rather specific to the Dutch societal context such as the lack of a national or regional curriculum or the lack of concrete national learning standards. Other aspects seem rather like those of other countries, such as the lack of consistency between higher-level standards and facilities and lower-level specification of concepts, tasks, and learning results in terms of double diagnostics (e.g., see Betebenner, 2009; Kemp, 2000; Lillard, 2012; Lubinski, 2004; Wheadon, 2013). Given the present Dutch experiences, some suggestions can be made to promote further development of optimal education in preschools and primary schools across European countries. These suggestions are as follows. 
1. The present prototype PDKS could be a research issue in the European context. Researchers from different countries can collaborate to compare and operationalise learning concepts and their hierarchic structuring in their national contexts and then in collaboration, identify a more or less overarching or core European structure to assist educational research across different countries and assist educational policy in aiming for optimal education for all pupils. Research collaboration in the form of a specifically designed European project would aid this undertaking.

2. As a second step, initial PDKS's within different European countries can be used to conduct research in preschool practice and at higher levels of educational attainment. Researchers from the countries involved can use comparable or other development and implementation approaches as was presented here, for use in their own country. They should collaborate closely in designing and developing specific PDKS-related curricular programmes that may partly be identical across countries. Such a European development approach will promote preventative educational support for all types of pupils (see Bennett et al., 2012; International Panel of Experts for Gifted Education, 2009; Mooij, 2013; Norwich et al., 2014) and support adequate evaluation of SRL and other types of learning during the whole school career (the 'value-added' by schools). Such innovation is also expected to increase the influence of the gifted on national economies (Shavinina, 2012).

3. In a third step, European attention could be focused on the ICT that is necessary to support the development in educational practice. This may involve the participation of national institutes that regularly do comparable ICT-based activities, or institutes developing software, to gain more strength and status in the development process.

4. If such partners as indicated in suggestion 3 are aiming at the same type of education, such as in the optimal education as presented in Table 1, these partners could be already involved during suggestion 2 (see above). What is most important is that ICT development should assist the educational innovation as proposed; in other words, pedagogical and psychological criteria should guide the development of ICTs, and not the other way around. This education-based strategy in developing ICT can be perceived also in some other contributions (see Andrade, this issue; Cebrián de la Serna et al., this issue; Raposo Rivas et al., this issue).

5. Finally, real preventative school development should start at the beginning of schooling. For a European project this means that to synchronise school development across countries attention should be paid first to preschool or kindergarten development, followed by development of primary schools, and so on. Simultaneously, development and research could start in secondary education and in higher levels, to avoid too much waiting for each other. For each educational type and level of achievement, particular emphasis should be directed at development and checks of appropriate levels and diagnostic procedures for pupils at risk and gifted pupils in particular (see also Mooij \& Smeets, 2009; Mooij, Steffens, \& Andrade, 2014).

\section{References}

Akker, J. van den, Maribe Branch, R., Gustafson, K., Nieveen, N., \& Plomp, T. (1999) Design 
Approaches and Tools in Education and Training. Dordrecht, The Netherlands: Kluwer.

Andrade, M.S. (this issue) Dialogue and Structure: enabling learner self-regulation in technology enhanced learning environments, European Educational Research Journal.

Arbeitsgruppe Schulforschung (1980) Leistung und Versagen [Performance and failure]. München, Germany: Juventa.

Bailey, R., Pearce, G., Smith, C., Sutherland, M., Stack, N., Winstanley, C., \& Dickenson, M. (2012) Improving the Educational Achievement of Gifted and Talented Students: a systematic review. Talent Development \& Excellence, 4(1), 33-48.

Banyard, P., Underwood, J., \& Twiner, A. (2006) Do enhanced Communication Technologies inhibit or facilitate Self-Regulated Learning? European Journal of Education, 41(3/4), 473-489.

Baroody, A.J. (1993) Fostering the Mathematical Learning of Young Children, in B. Spodek (Ed) Handbook of Research on the Education of Young Children. New York: MacMillan.

Beirn, R., Kinsey, D.C., \& McGinn, N.F. (1972) Antecedents and Consequences of Early School Leaving, Educational Documentation and Information, 46(182), 1-116.

Bennathan, M. \& Boxall, M. (1996) Effective Intervention in Primary Schools. Nurture Groups. London: David Fulton.

Bennett, J., Gordon, J., \& Edelmann, J. (2012) Early Childhood Education and Care (ECEC) for Children from Disadvantaged Backgrounds: findings from a European literature review and two case studies. Brussels, Belgium: European Commission, Directorate General for Education and Culture. http://ec.europa.eu/education/moreinformation/doc/ecec/report_en.pdf

Black, P., McCormick R., James, M., \& Pedder, D. (2006) Learning how to Learn and Assessment for Learning: a theoretical inquiry, Research Papers in Education, 21(2), 119132.

Bergqvist, K. \& Säljö, R. (1998) Construction of Curricular Content in the Individualised Age-Integrated Classroom. Paper presented at European Conference on Educational Research (ECER), 17-20 September, Ljubljana, Slovenia.Betebenner, D. (2009) Normand Criterion-Referenced Student Growth, Educational

Measurement: Issues and Practice, 28(4), 42-51.

Blumenfeld, P., Fishman, B.J., Kraycik, J., Marx, R.W., \& Soloway, F. (2000) Creating usable Innovations in Systemic Reform: scaling up technology-embedded projects-based science in urban schools, Educational Psychologist, 35, 149-164.

Boom, G. van den, Paas, F., Merriënboer, J.J.G. van, \& Gog, T. van (2004) Reflection Prompts and Tutor Feedback in a Web-Based Learning Environment: effects on students' self-regulated learning competence, Computers in Human Behavior, 20, 551-567.

Bowerman, W.R. (1978) Subjective Competence: the structure, process and function of selfreferent causal attributions, Journal for the Theory of Social Behaviour, 8, 45-75.

Brown, S.W., Renzulli, J.S., Gubbins, E.J., Siegle, D., Zhang, W., \& Chen, C.-H (2005) Assumptions underlying the Identification of Gifted and Talented Students, Gifted Child Quarterly, 49, 68-79.

Brush, T. \& Saye, J. (2001) Defining Hard and Soft Scaffolding in Technology-Enhanced Student Centered Learning Environments. Paper presented at Association for Educational Communications and Technology (AECT), 8-10 November. Atlanta, USA. 
Byrne, B. (1998) The Foundation of Literacy. The Child's Acquisition of the Alphabetic Principle. Hove, UK: Psychology Press.

Carneiro, R. (2006) Motivating School Teachers to Learn: can ICT add value? European Journal of Education, 41(3/4), 415-435.

Cebrián Robles, D., Serrano Angulo, J., \& Cebrián de la Serna, M. (this issue) Federated eRubric Service to Facilitate Self-Regulated Learning in the European University Model, European Educational Research Journal.

Chapman, R.L., Buckley, L., Sheehan, M., \& Shochet, I. (2013) School-Based Programs for Increasing Connectedness and Reducing Risk Behavior: a systematic review, Educational Psychology Review, 25, 95-114.

Chen, K. (2006) Social Skills Intervention for Students with Emotional/Behavioral Disorders: a literature review from the American perspective, Educational Research and Reviews, 1(3), 143-149.

Clark, R.E. \& Estes, F. (1999) The Development of Authentic Educational Technologies, Educational Technology, 39(2), 5-16.

Cobb, P., Confrey, J., diSessa, A., Lehrer, R., \& Schauble, L. (2003) Design Experiments in Educational Research, Educational Researcher, 32(1), 9-13.

Colangelo, N., Assouline, S.N., \& Gross, M.U.M. (Eds) (2004) A Nation Deceived: how schools hold back America's brightest students (Volumes I and II). Iowa City, IA: The Connie Belin and Jacqueline N. Blank International Center for Gifted Education and Talent Development.

Collier, G. (1994) Social Origins of Mental Ability. New York: Wiley.

Crook, C. (1998) Children as Computer Users: the case of collaborative learning, Computers \& Education, 30, 237-247.

Dijkstra, E, \& Mooij, T. (2012) Screening 'Beginkenmerken vierjarigen' door ouders en leerkrachten [Screening 'Beginning characteristics of four-year olds' by parents and teachers]. Nijmegen/Heerlen: Radboud Universiteit, ITS Nijmegen / Open Universiteit, CELSTEC.

Dijkstra, E. M., Walraven, A., Mooij, T., \& Kirschner, P. A. (in preparation a) Factors Affecting Implementation of Differentiated Instruction for High-Ability Children in Kindergarten.

Dijkstra, E. M., Walraven, A., Mooij, T., \& Kirschner, P. A. (in preparation b) Improving Kindergarten Teachers' Use of Differentiated Instruction to Anticipate Pupil Differences.

Dijkstra, E. M., Walraven, A., Mooij, T., \& Kirschner, P. A. (submitted a) Unravelling Academic Underachievement and Behavioural Problems of Gifted Pupils: Explanations and Solutions.

Dijkstra, E. M., Walraven, A., Mooij, T., \& Kirschner, P. A. (submitted b) Effects of Teacher Differentiation Practices on Kindergarten Children's Cognitive and Social Outcomes.

Doolaard, S. \& Oudbier, M. (2010) Onderwijsaanbod aan (hoog)begaafde leerlingen in het basisonderwijs [Education for Gifted Pupils in Primary Education]. Groningen, The Netherlands: University of Groningen.

Driessen, G. (2013) De bestrijding van onderwijsachterstanden [Promoting Education for 
Disadvantaged Groups]. Nijmegen, The Netherlands: Radboud University, ITS.

Durkin, D. (1966) Children who read early. New York: Teachers College Press.

Earle, R.S. (Ed) (2001) Standards for the Accreditation of Programs in Educational Communications and Instructional Technology (ECIT) ( $4^{\text {th }}$ Rev. ed., October 2001). Bloomington, Indiana: Technos press of the Agency for Instructional Technology (AIT) / Association for Educational Communications and Technology (AECT).

Ely, D.P. (1999) Conditions that facilitate the implementations of educational technology innovations, Educational Technology, 39(6), 23-27.

Gagné, F. (2011) Academic Talent Development and the Equity Issue in Gifted Education, Talent Development \& Excellence, 3(1), 3-22.

Gallagher, J.J. (1975) Teaching the Gifted Child. Boston: Allyn and Bacon.

Groot, A.D. de (1966) Vijven en Zessen [(In)sufficient School Marks]. Groningen, The Netherlands: Wolters-Noordhoff.

Gustafson, K. (2002) Instructional Design Tools: a critique and projections for the future, Educational Technology Research and Development, 50(4), 59-66.

Händel, M., Vialle, W., \& Ziegler, A. (2013) Student Perceptions of High-Achieving Classmates, High Ability Studies, 24(2), 99-114.

Heckhausen, H. (1980) Motivation und Handeln: Lehrbuch der Motivationspsychologie [Motivation and Action: Handbook of Motivational Psychology]. Berlin: Springer.

Hepler, J.B. (1998) Social Integration of Children with Emotional Disabilities and Nonhandicapped Peers in a School Setting, Early Child Development and Care, 147, 99115.

Hermanns, J. (1979) Het ontstaan van Schoolproblemen. Een longitudinaal onderzoek in kleuter- en lagere school [Emergence of Problems at School. A longitudinal study in preschool and primary school], Pedagogische Studiën, 56, 348-357.

Hermanns, J. (1980) Het ontstaan van Schoolproblemen (II). Gedragsobservatie door kleuterleidsters [Emergence of Problems at School (II). Behavioural observation by preschool teachers], Pedagogische Studiën, 57, 11-21.

Hermanns, J., Öry, F., \& Schrijvers, G. (2005) Helpen bij Opgroeien en Opvoeden: eerder, sneller en beter. Een advies over vroegtijdige signalering en interventies bij opvoed- en opgroeiproblemen [Helping to Grow and Educate: earlier, faster and better. Advice on early identification and intervention concerning pedagogical and growth problems]. http://www.integratedcare.nl.

Jewett, J., Tertell, Liz, King-Taylor, M., Parker, D., Tertell, Lin, \& Orr, M. (1998) Four Early Childhood Teachers reflect on helping Children with Special Needs make the Transition to Kindergarten, The Elementary School Journal, 98(4), 329-338.

International Panel of Experts for Gifted Education (iPEGE) (2009) Professional Promotion of the Gifted and Talented: Recommendations for the Qualification of Experts in Gifted Education. Salzburg, Austria: Austrian Research and Support Center for the Gifted and Talented (Österreichisches Zentrum für Begabtenförderung und Begabungsforschung, özbf).

http://www.oezbf.net/cms/tl_files/Publikationen/Veroeffentlichungen/iPEGE_1_english.pd $\mathrm{f}$ 
James, M., Black, P., McCormick, R., Pedder, D., \& William, D. (2006) Learning how to Learn, in Classrooms, Schools and Networks: aims, design and analysis, Research Papers in Education, 21(2), 101-118.

Kalyuga, S. (2007) Expertise Reversal Effect and its Implications for Learner-Tailored Instruction, Educational Psychology Review, 19(4), 509-539.

Kemp, J.E. (2000) An Interactive Guidebook for Designing Education in the $21^{\text {st }}$ Century. Bloomington, Indiana: Technos press of the Agency for Instructional Technology (AIT) / Association for Educational Communications and Technology (AECT).

Kohnstamm, P. (1928) Persoonlijkheid in Wording [On becoming a Personality]. Haarlem, The Netherlands: Tjeenk Willink.

Kreijns, K., Kirschner, P.A., \& Jochems, W. (2003) Identifying the Pitfalls for Social Interaction in Computer-Supported Collaborative Learning Environments: a review of the research, Computers in Human Behavior, 19, 335-353.

Lems, J. (1996) Kleuteropvoeding in 't geding. Jonge kinderen de dupe van slecht beleid [Preschool Education at risk. Young children are the victims of bad policy]. Hilversum: The Netherlands: Author.

Leseman, P.P.M. (2002) Onderzoek in de Voor-en Vroegschoolse Periode: trends en nieuwe vragen [Research: before school and in the early schooling period: trends and new questions]. The Hague, The Netherlands: NWO / PROO.

Lillard, A.S. (2012) Preschool Children's Development in Classic Montessori, supplemented Montessori, and Conventional Programs, Journal of School Psychology, 50, 379-401.

Livingstone, S. (2003) Children's Use of the Internet: reflections on the emerging research agenda, New Media \& Society, 5(2), 147-166.

Livingstone, S. \& Helsper, E., (2008) Parental Mediation and Children's Internet Use, Journal of Broadcasting \& Electronic Media, 52(4), 581-599.

Lubinski, D. (2004) Long-Term Effects of Educational Acceleration, in N. Colangelo, S.G. Assouline \& M.U.M. Gross (Eds) A Nation Deceived. How schools hold back America's brightest students (Vol. 2, pp. 23-37). Iowa City, IA: The University of Iowa, International Center for Gifted Education and Talent Development.

Magnusson, D. \& Allen, V.L. (Eds) (1983) Human Development. An interactional perspective. New York: Academic Press.

Meijer, C.J.W. (Ed) (2003) Inclusive Education and Effective Classroom Practices. Middelfart, Denmark: European Agency for Development in Special Needs Education.

Meijer, J., Ledoux, G., \& Elshof, D. (2011) Gebruikersvriendelijke Leerlingvolgsystemen in het Primair Onderwijs [User-friendly Pupil Monitoring Systems in Primary Education]. Amsterdam: Kohnstamm Instituut.

Mooij, T. (1992) Predicting (Under)achievement of Gifted Children, European Journal for High Ability, 3, 59-74.

Mooij, T. (1994) Begaafd in Groep 1/2. Omgaan met (hoog)begaafde kinderen (1) [Being Gifted in Preschool: how to get along with young gifted children (1)], Het Jonge Kind, 22, 102-106.

Mooij, T. (1999) Integrating Gifted Children into Kindergarten by Improving Educational Processes, Gifted Child Quarterly, 43(2), 63-74.

Mooij, T. (2000) Screening Children's Entry Characteristics in Kindergarten, Early Child 
Development and Care, 165, 23-40.

Mooij, T. (2002) Designing a Digital Instructional Management System to Optimize Early Education, Educational Technology Research \& Development, 50(4), 11-23.

Mooij, T. (2004) Optimising ICT Effectiveness in Instruction and Learning: multilevel transformation theory and a pilot project in secondary education, Computers \& Education, 42(1), 25-44.

Mooij, T. (2006) Theoretical and Methodological Significance of Information and Communication Technology in Educational Practice, European Educational Research Journal, 5(2), 77-79.

Mooij, T. (2007a) Design of Educational and ICT Conditions to Integrate Differences in Learning: contextual learning theory and a first transformation step in early education, Computers in Human Behavior, 23(3), 1499-1530.

Mooij, T. (2007b) Learning for Self-Regulation: improving instructional benefits for pupils, teachers, parents, schools, and society at large. Heerlen, The Netherlands: Open University of The Netherlands (OUNL).

Mooij, T. (2008) Education and Self-Regulation of Learning for Gifted Pupils: systemic design and development, Research Papers in Education, 23(1), 1-19.

Mooij, T. (2009) Education and ICT-Based Self-Regulation in Learning: theory, design and implementation, Education and Information Technologies, 14(1), 3-27.

Mooij, T. (2010) Schoolontwikkeling en Optimalisering van Leerprocessen [School Development and Optimalisation of Learning Processes], in J.R.M. Gerris, J.W. Veerman \& A. Tellings (Eds) Jeugd-en gezinsbeleid vanuit pedagogisch perspectief. Deel 2: Uitgewerkte beleidsthema's [Pedagogical Perspective on Youth and Family Policy. Part 2: Policy Themes Elaborated (pp. 249-269). Antwerpen, Belgium / Apeldoorn, The Netherlands: Garant.

Mooij, T. (2013) Designing Education and Learning for Cognitively Gifted Pupils in Preschool and Primary School, International Journal of Inclusive Education, 17(6), 579613.

Mooij, T. \& Driessen, G. (2008) Differential Ability and Attainment in Language and Arithmetic of Dutch Primary School Pupils, British Journal of Educational Psychology, 78, 491-506.

Mooij, T., Haverkort, J., \& de Kleijne, J. (2013) Pedagogisch-didactische, organisatorische en ICT-vereisten ter optimalisering van Integrale Kind Centra: Verslag van een vooronderzoek [Pedagogical-Didactic, Organisational and ICT requirements to optimise Integral Centres for Children: Report of a pilot]. Nijmegen, The Netherlands: Stichting Conexus \& ITS, Radboud Universiteit; Oosterhout: Stichting Delta-onderwijs; Geldermalsen: Stichting Fluvium.

Mooij, T., Hoogeveen, L. Driessen, G., van Hell, J., \& Verhoeven, L. (2007) Succescondities voor onderwijs aan hoogbegaafde leerlingen [Success conditions of Education for High Ability Pupils]. Nijmegen, The Netherlands: Radboud Universiteit, ITS / CBO / Afdeling Orthopedagogiek.

Mooij, T., Roeleveld, J., Fettelaar, D., \& Ledoux, G. (2012) Kwaliteitsbeoordeling van Scholen Primair Onderwijs: het correctiemodel van de inspectie vergeleken met 
alternatieve modellen [Judging the Quality of Primary Schools: comparing the model of the Education Inspectorate with alternative models], Pedagogische Studiën, 89(5), 272287.

Mooij, T. \& Smeets, E. (2001) Modelling and Supporting ICT Implementation in Secondary Schools, Computers \& Education, 36(3), 265-281.

Mooij, T. \& Smeets, E. (2009) Towards Systemic Support of Pupils with Emotional and Behavioural Disorders, International Journal of Inclusive Education, (13)6, 597-616.

Mooij, T., Steffens, K., \& Andrade, M.S. (this issue) Self-Regulated and TechnologyEnhanced Learning: a European perspective, European Educational Research Journal.

Moss, E. \& Strayer, F.F. (1990) Interactive Problem-Solving of Gifted and Non-gifted Preschoolers with their Mothers, International Journal of Behavioral Development, 13, 177-197.

Nieveen, N. \& Kuiper, W. (2012) Balancing Curriculum Freedom and Regulation in the Netherlands, European Educational Research Journal, 11(3), 357-368.

Norwich, B., Ylonen, A., \& Gwernan-Jones, R. (2014) Moderate learning difficulties: searching for clarity and understanding, Research Papers in Education, 29(1), 1-19.

Overtoom, R. (1991) Informatieverwerking door Hoogbegaafde Leerlingen bij het oplossen van Wiskundeproblemen [Information Processing by Gifted Pupils; solving problems in mathematics]. De Lier, The Netherlands: Academisch Boeken Centrum.

Parkhurst, H. (1922) Education on the Dalton Plan. New York: Dutton.

Perels, F., Gürtler, T., \& Schmitz, B. (2005) Training of Self-Regulatory and ProblemSolving Competence, Learning and Instruction, 15(2), 123-139.

Pino-Pasternak, D. \& Whitebread, D. (2010) The Role of Parenting in Children's SelfRegulated Learning, Educational Research Review, 5, 220-242.

Pol, J. van de, Volman, M., \& Beishuizen, J. (2010) Scaffolding in Teacher-Student Interaction: a decade of research, Educational Psychology Review, 22, 271-296.

Purcell, J.H., Burns, D.E., Tomlinson, C.A., Imbeau, M.B., \& Martin, J.L. (2002) Bridging the Gap: a tool and technique to analyze and evaluate gifted education curricular units, Gifted Child Quarterly, 46, 306-321.

Raposo Rivas, M., Cebrián de la Serna, M., \& Martínez-Figueira, E. (this issue) Electronic Rubrics to Assess Competences in ICT Subjects, European Educational Research Journal.

Reynolds, N. (2005) The Computer as Scaffold, Tool and Data Collector: children composing with computers, Education and Information Technologies, 10(3), 239-248.

Robinson, J.B., Burns, B.M., \& Winder Davis, D. (2009) Maternal Scaffolding and Attention Regulation in Children living in Poverty, Journal of Applied Developmental Psychology, 30, 82-91.

Rozendaal, J.S., Minnaert, A., \& Boekaerts, M. (2005) The Influence of Teacher perceived Administration of Self-Regulated Learning on Students' Motivation and InformationProcessing, Learning and Instruction, 15(2), 141-160.

Shavinina, L.V. (2012) The Emergence of a New Research Direction at the Intersection of Talent and Economy: the influence of the gifted on economy, Talent Development \& Excellence, 4(1), 65-88.

Sinko, M. \& Lehtinen, E. (1999) The Challenges of ICT in Finnish Education. Jyväskylä, Finland: Atena. 
Skinner, D., Bryant, D., Coffman, J., \& Campbell, F. (1998) Creating Risk and Promise Children's and Teachers' Coconstructions in the Cultural World of Kindergarten, The Elementary School Journal, 98, 297-310.

Slinger, J.D., Trijp, S.M.A. van, Verheijden, M.W., \& Empelen, P. van (2011) Leerlingvolgsysteem op het Gebied van Beweging, Gewicht, Schooluitval en Talentontwikkeling [Pupil Monitoring Systems in the Areas: motion, weight, drop-out and talent development]. Leiden, The Netherlands: TNO Behavioural and Societal Sciences.

Sontag, C., Stoeger, H., \& Harder, B. (2012) The Relationship between Intelligence and the Preference for Self-Regulated Learning: a longitudinal study with fourth-graders, Talent Development \& Excellence, 4(1), 1-22.

Steffens, K. (2006) Self-Regulated Learning in Technology-Enhanced Learning Environments: lessons of a European peer review, European Journal of Education, 41(3/4), 353-379.

Steffens, K. (this issue) ICT Use and Achievement in three European Countries: what does PISA tell us? European Educational Research Journal.

The Scottish Government (2009) Curriculum for Excellence. Building the Curriculum 4 Skills for Learning, Skills for Life and Skills for Work. Edinburgh, Scotland: The Scottish Government. http://www.scotland.gov.uk/Resource/Doc/288517/0088239.pdf

Tymms, P., Merrel, C., \& Henderson, B. (2000) Baseline Assessment and Progress during the first three Years at School, Educational Research and Evaluation, 6(2), 105-129.

Walsh, R.L., Hodge, K.A., Bowes, J.M., \& Kemp, C.R. (2010) Same Age, Different Page: overcoming the barriers to catering for young gifted children in prior-to-school settings, International Journal of Early Childhood, 42(1), 43-58.

Watkins, A. (2001) Information and Communication Technology (ICT) in Special Needs Education (SNE). Middelfart, Denmark: European Agency for Development in Special Needs Education.

Wheadon, C. (2013) Using modern Test Theory to maintain Standards in Public Qualifications in England, Research Papers in Education, 28(5), 628-647.

Zimmerman, B.J. (1990) Self-Regulated Learning and Academic Achievement: an overview, Educational Psychologist, 25(1), 3-17.

Zimmerman, B.J. (2000) Attaining Self-Regulation: a social cognitive perspective, in M. Boekaerts, P.R. Pintrich \& M. Zeidner (Eds), Handbook of Self-Regulation. San Diego, CA: Academic Press.

Zimmerman, B.J. (2002) Achieving Academic Excellence: a self-regulatory perspective, in M. Ferrari (Ed), The Pursuit of Excellence through Education. Hillsdale, NJ: Erlbaum. 
Table I: Educational conditional dimensions, learning aspects, and guidelines for designing education for optimal learning

\begin{tabular}{|c|c|c|c|}
\hline \multirow{2}{*}{$\begin{array}{l}\text { Learning } \\
\text { aspects }\end{array}$} & \multicolumn{3}{|c|}{ Educational conditional dimensions } \\
\hline & $\begin{array}{l}\text { Differentiation of learning } \\
\text { materials and procedures }\end{array}$ & $\begin{array}{l}\text { Integration and use of ICT } \\
\text { support }\end{array}$ & $\begin{array}{l}\text { Strategies to improve } \\
\text { development and learning }\end{array}$ \\
\hline Diagnostic & $\begin{array}{l}\text { 1.1. Identify a pedagogical- } \\
\text { didactic kernel structure for } \\
\text { different domains and } \\
\text { subdomains }\end{array}$ & $\begin{array}{l}\text { 2.1. Facilitate construction and } \\
\text { use of a pedagogical-didactic } \\
\text { kernel structure }\end{array}$ & $\begin{array}{l}\text { 3.1. Use a learner's entry-level } \\
\text { characteristics to start } \\
\text { instructional lines }\end{array}$ \\
\hline \multirow[t]{2}{*}{ Instructional } & $\begin{array}{l}\text { 1.2. Structure domains of } \\
\text { competence in terms of skills, } \\
\text { subskills and instructional lines }\end{array}$ & $\begin{array}{l}\text { 2.2. Enhance structuring and } \\
\text { flexible use of instructional } \\
\text { lines and learning arrangements }\end{array}$ & $\begin{array}{l}\text { 3.2. Create and control } \\
\text { prosocial relationships in and } \\
\text { around school }\end{array}$ \\
\hline & $\begin{array}{l}\text { 1.3. Include criterion-based and } \\
\text { normed indicators to evaluate } \\
\text { learning progress }\end{array}$ & $\begin{array}{l}\text { 2.3. Facilitate differential } \\
\text { instruction, collaborative } \\
\text { learning, and self-regulation }\end{array}$ & $\begin{array}{l}\text { 3.3. Use collaborative didactic } \\
\text { procedures to stimulate self- } \\
\text { regulation across years }\end{array}$ \\
\hline Managerial & $\begin{array}{l}\text { 1.4. Organise and match } \\
\text { flexible groups of learners and } \\
\text { teachers/coaches }\end{array}$ & $\begin{array}{l}\text { 2.4. Encourage differentiated } \\
\text { and multilevel evaluation of } \\
\text { learning progress }\end{array}$ & $\begin{array}{l}\text { 3.4. Concentrate teacher } \\
\text { coaching on those pupils most } \\
\text { in need of this }\end{array}$ \\
\hline Systemic & $\begin{array}{l}\text { 1.5. Use integrated systems for } \\
\text { monitoring, evaluation, and } \\
\text { administration }\end{array}$ & $\begin{array}{l}\text { 2.5. Integrate instruction and } \\
\text { learning across different } \\
\text { contexts and points in time }\end{array}$ & $\begin{array}{l}\text { 3.5. Apply multilevel indicators } \\
\text { to improve instruction and } \\
\text { learning throughout school }\end{array}$ \\
\hline
\end{tabular}

Table II: Reliability coefficients (Cronbach's Alpha) of screening scales completed by infant day-care centres, parents, and preschool

\begin{tabular}{|c|c|c|c|c|c|c|c|c|c|c|}
\hline \multirow[b]{3}{*}{ Scales (number of items) ${ }^{\mathrm{b}}$} & \multicolumn{6}{|c|}{ Pilot preschool East } & \multicolumn{4}{|c|}{ National study ${ }^{\mathrm{a}}$} \\
\hline & \multicolumn{2}{|c|}{ Day-care } & \multicolumn{2}{|c|}{ Parents } & \multicolumn{2}{|c|}{ Preschool } & \multicolumn{2}{|c|}{ Parents } & \multicolumn{2}{|c|}{ Preschool } \\
\hline & $\mathrm{N}$ & Alpha & $\mathrm{N}$ & Alpha & $\mathrm{N}$ & Alpha & $\mathrm{N}$ & Alpha & $\mathrm{N}$ & Alpha \\
\hline Social-communicative level (2) & 52 & .97 & 134 & .97 & 118 & .91 & 752 & .92 & 749 & .88 \\
\hline General cognitive level (4) & 51 & .87 & 133 & .62 & 117 & .82 & 736 & .65 & 745 & .80 \\
\hline Language proficiency level (5) & 34 & .97 & 113 & .82 & 106 & .86 & 703 & .80 & 686 & .87 \\
\hline Pre-arithmetic level (4) & 30 & .89 & 119 & .84 & 109 & .92 & 697 & .76 & 680 & .90 \\
\hline Emotional-expressive level (5) & 45 & .87 & 131 & .87 & 116 & .82 & 737 & .68 & 714 & .78 \\
\hline Senso-motor level (4) & 50 & .88 & 124 & .77 & 109 & .81 & 739 & .65 & 733 & .75 \\
\hline Expected educ. beh./motiv. (4) & 48 & .93 & 131 & .83 & 116 & .85 & 733 & .84 & 711 & .91 \\
\hline
\end{tabular}


Table III: N, mean and SD of screening scales completed by infant day-care centres, parents, and preschool ${ }^{\mathrm{a}}$

\begin{tabular}{lccccccccc}
\hline & \multicolumn{3}{c}{ Day-care centres } & \multicolumn{3}{c}{ Parents } & \multicolumn{4}{c}{ Preschool teachers } \\
\cline { 2 - 10 } Screening scales & $\mathrm{N}$ & $\mathrm{M}$ & $\mathrm{SD}$ & $\mathrm{N}$ & $\mathrm{M}$ & $\mathrm{SD}$ & $\mathrm{N}$ & $\mathrm{M}$ & $\mathrm{SD}$ \\
\hline Social-communicative level & 52 & 3.42 & .79 & 135 & 3.21 & .77 & 119 & 3.45 & .73 \\
General cognitive level & 53 & 3.59 & .71 & 136 & 3.50 & .56 & 119 & 3.64 & .63 \\
Language proficiency level & 53 & 3.28 & .58 & 136 & 3.42 & .72 & 119 & 3.51 & .70 \\
Pre-arithmetic level & 52 & 3.23 & .65 & 134 & 3.35 & .66 & 116 & 3.54 & .70 \\
Emotional-expressive level & 53 & 3.42 & .73 & 136 & 3.48 & .65 & 119 & 3.55 & .66 \\
Senso-motor level & 53 & 3.47 & .78 & 136 & 3.23 & .67 & 119 & 3.37 & .63 \\
Expected educ. behav./motiv. & 50 & 3.50 & .67 & 136 & 3.40 & .51 & 118 & 3.58 & .58 \\
\hline
\end{tabular}

${ }^{\text {a }}$ Scale scores based on inclusion of information of all available item scores.

Table IV: Differences (paired t-tests) between mean entry characteristics scored by infant daycare centres, parents, and preschool

\begin{tabular}{|c|c|c|c|c|c|c|c|c|c|}
\hline \multirow[b]{2}{*}{ Screening scales } & \multicolumn{2}{|c|}{ Mean $^{\mathrm{a}}$} & \multicolumn{3}{|c|}{ Mean $^{\mathrm{b}}$} & \multicolumn{4}{|c|}{$\operatorname{Mean}^{\mathrm{c}}$} \\
\hline & Day-care & Parents & $\mathrm{T}^{\mathrm{d}}$ & Day-care & $\begin{array}{c}\text { Preschoo } \\
1\end{array}$ & $\mathrm{~T}^{\mathrm{d}}$ & Parents & $\begin{array}{c}\text { Preschoo } \\
1\end{array}$ & $\mathrm{~T}^{\mathrm{d}}$ \\
\hline Social-communicative level & 3.43 & 3.32 & -.62 & 3.43 & 3.41 & -.15 & 3.18 & 3.46 & $-3.49 * *$ \\
\hline General cognitive level & 3.60 & 3.57 & -.32 & 3.60 & 3.53 & -.59 & 3.52 & 3.63 & -1.91 \\
\hline Language proficiency level & 3.28 & 3.41 & 1.24 & 3.28 & 3.44 & 1.48 & 3.39 & 3.49 & -1.58 \\
\hline Pre-arithmetic level & 3.24 & 3.36 & 1.12 & 3.22 & 3.55 & $2.93^{*}$ & 3.36 & 3.52 & $-2.76^{*}$ \\
\hline Emotional-expressive level & 3.43 & 3.67 & 1.82 & 3.42 & 3.55 & 1.43 & 3.50 & 3.56 & -1.14 \\
\hline Senso-motor level & 3.48 & 3.20 & $-2.33^{*}$ & 3.48 & 3.24 & $-2.23 *$ & 3.23 & 3.37 & $-2.41 *$ \\
\hline Expected educ. beh./motiv. & 3.51 & 3.45 & -.58 & 3.52 & 3.57 & .49 & 3.39 & 3.58 & $-3.38 * *$ \\
\hline
\end{tabular}

${ }^{\mathrm{a}} \mathrm{N}$ ranges from 49 to $52 ;{ }^{\mathrm{b}} \mathrm{N}$ ranges from 47 to $50 ;{ }^{\mathrm{c}} \mathrm{N}$ ranges from 108 to 111 .

$\mathrm{d} * .01 \leq \mathrm{p} \leq .05 ; * * \mathrm{p}<.01$. 
Table V: Pearson correlations between entry characteristics scored by infant day-care centres, parents, and preschool

Soc.-comm. Gener. cogn. Lang.prof. Pre-arithm. Emot.expr. Sensorimotor

Day-care centres ${ }^{a}$

General cognitive level $\quad .53 * *$

Language proficiency level $.24 \quad .67 * *$

Pre-arithmetic level $\quad .40 * * \quad .64 * *$

Emotional-expressive level $.76 * * \quad 80 * *$

Senso-motor level . $\quad .64 * *$

$.64 * *$

$43 * *$

$.81 * *$

$.39 * *$

$.53 * *$

Expected ed. behav./motiv. .74**

$.47 * *$

$.38 * *$

$.53 * *$

Parents $^{b}$

General cognitive level $\quad .15$

Language proficiency level .01

Pre-arithmetic level $\quad .02$

$.56 * *$

Pre-arithmetic level .02

$.56 * * \quad .63 * *$

Emotional-expressive level .44**

$21 *$

$.21 *$

$.21 *$

.12

Senso-motor level $\quad .30 * *$

$.38 * *$

$.26 * *$

$.35 * *$

$.67 * *$

$.58 * *$

$.63 * *$

$.29 * *$

Expected ed. behav./motiv. .33**

Preschool teachers ${ }^{c}$

General cognitive level .29**

Language proficiency level .10

$.70 * *$

Pre-arithmetic level $\quad-.08$

Emotional-expressive level .54**

$.50 * *$

$.41 * *$

$.68 * *$

Senso-motor level

$.64 * *$

${ }^{\mathrm{a}} \mathrm{N}$ ranges from 50 to $53 ;{ }^{\mathrm{b}} \mathrm{N}$ ranges from 133 to $136 ;{ }^{\mathrm{c}} \mathrm{N}$ ranges from 116 to 119.

$\mathrm{d} * .01 \leq \mathrm{p} \leq .05 ; * * \mathrm{p}<.01$. 


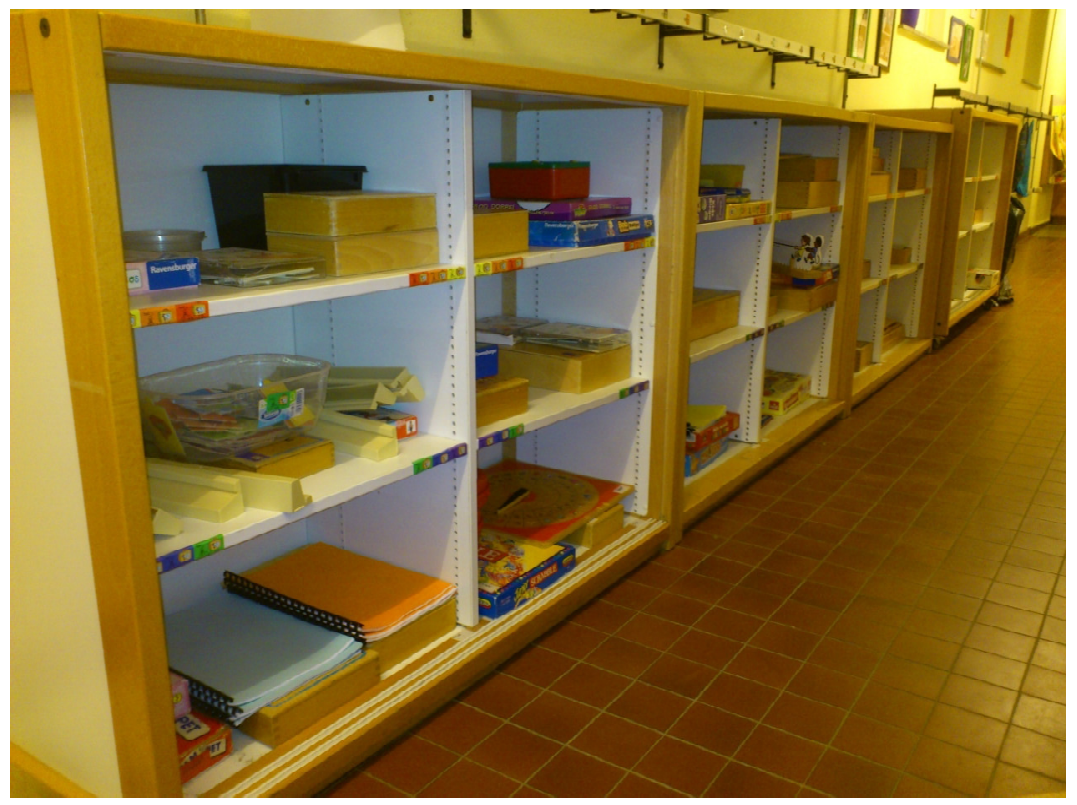

Figure 1: PDKS-related ordering of playing and learning materials for preschool years 1-2 integrated with primary school year 3

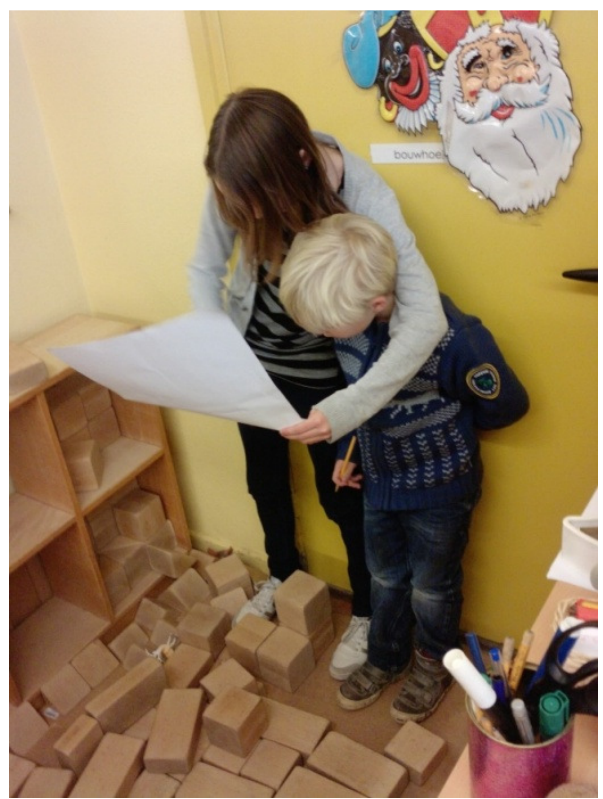

Figure 2: Self-regulation and collaboration between pupils: same task, different age 


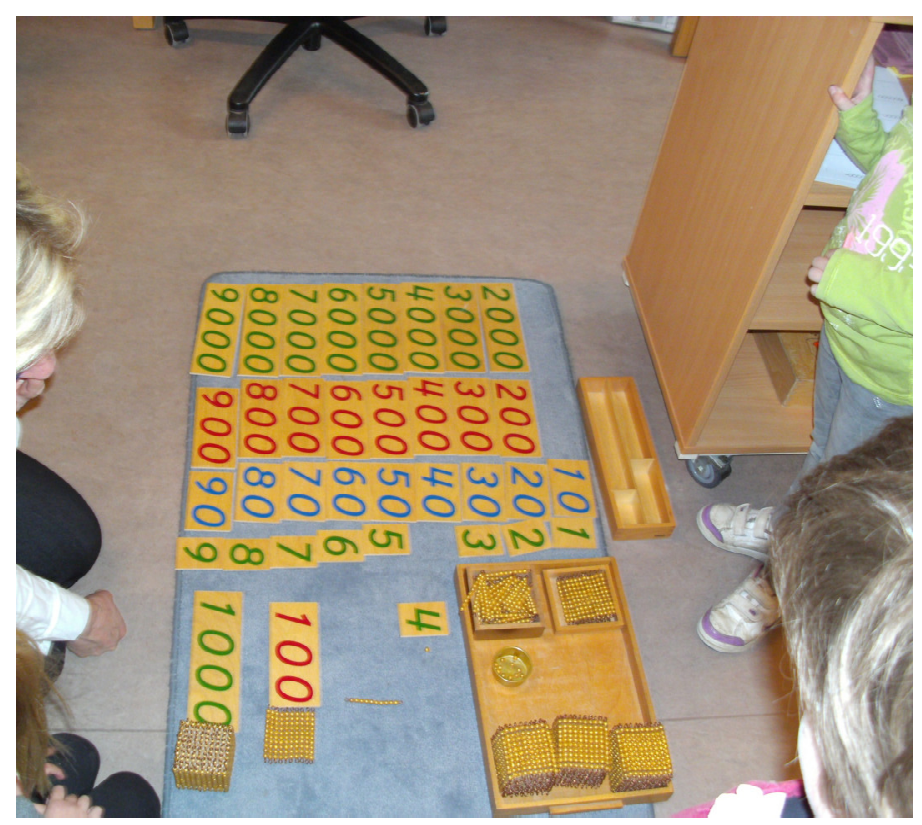

Figure 3: Self-regulation and collaboration between pupils: about four years above age level (double diagnostics)

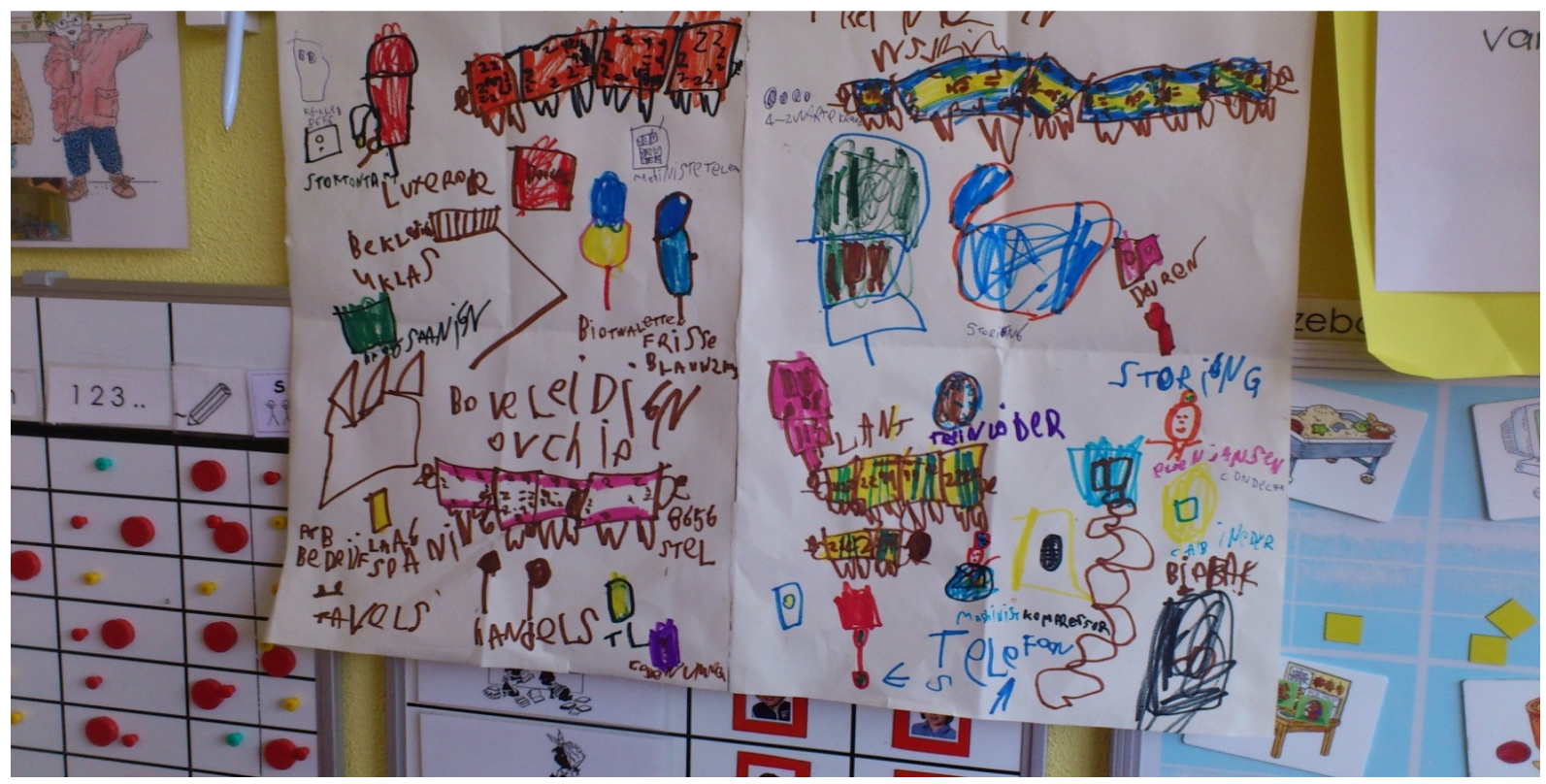

Figure 4: Self-regulation and collaboration between preschool pupils: presenting results of free activities 